\title{
TRANSFER OF IN VITRO SYNTHESIZED VICIA FABA GLOBULINS AND BARLEY PROLAMINS ACROSS THE ENDOPLASMIC RETICULUM MEMBRANE OF VICIA FABA
}

by

\author{
ERNST WEBER ${ }^{1,2}$, JOHN INGVERSEN², RENATE MANTEUFFEL ${ }^{1}$ \\ and MANFRED PÜCHEL'
}

\begin{abstract}
IZntralinstitut für Genetik und Kulturpflanzenforschung der Akademie der Wissenschaften der DDR, Corrensstrasse 3, DDR-4325 Gatersleben

2 Department of Physiology, Carlsberg Laboratory, Gamle Carlsberg Vej 10, DK-2500 Copenhagen Valby
\end{abstract}

Keywords: Hordeum vulgare, legumin, vicilin, hordein, membrane transport, reconstituted microsomes

Initially membrane bound polysomes, microsomes and total cellular polyadenylated RNA were isolated from developing cotyledons of Vicia faba. The templates were translated in vitro employing the wheat germ system (polysomes and microsomes) or the rabbit reticulocyte system (poly-A RNA). The translation products were isolated with antibodies raised against vicilin and legumin and analyzed by SDS-polyacrylamide gel electrophoresis. Vicilin was synthesized as one major $\mathrm{N}$-terminally extended precursor molecule, with a molecular weight of about 52,000 . The precursor was vectorially discharged through the membrane of the endoplasmic reticulum in conjunction with removal of the $\mathrm{N}$-terminal extension. Legumin isolated from mature Vicia faba seeds consists of two subunits which are linked by cystin bridges and have molecular weights of about 36,000 and 20,000 , respectively. These two subunits are known to be processed from a precursor molecule of 60,000 molecular weight. Applying antibodies raised against a purified legumin fraction for immunoaffinity isolation of in vitro translation products from polysomal, microsomal and mRNA templates yielded several polypeptides. The largest four of the polypeptides occurred in pairs with molecular weights around 51,000 and 60,000 , respectively. These and one lower molecular weight polypeptide were co-translationally transported into the lumen of the endoplasmic reticulum. Hybrid microsomes were reconstituted from Vicia faba stripped microsomes and initially membrane bound polysomes isolated from barley endosperm. These microsomes served as an active template for the in vitro synthesis of hordein - the storage protein of barley endosperm. Furthermore, hordein was vectorially discharged through the Vicia faba microsomal membranes.

Abbreviations: $\quad$ DOC $=$ sodium deoxycholate $;$ DTT $=$ dithiothreitol $;$ HEPES $=\mathrm{N}-2$-hydroxyethyl-piperazineN'-2-ethane sulfonic acid; HKM = HEPES-K-Mg acetate buffer (see 2.1); $\mathrm{IgG}=$ immunoglobulin G; mol.wt. $=$ molecular weight; SDS-PAGE = Sodium dodecylsulfate polyacrylamide gel electrophoresis; $\mathrm{TCA}=$ trichloroacetic acid. 


\section{INTRODUCTION}

The mature legume seed contains $20-25 \%$ protein of which $75 \%$ is accounted for by the storage globulins vicilin and legumin. Eleven $\mathrm{S}$ legumin is composed of two subunits, $\alpha-$ and $\beta$ legumin with apparent molecular weights of about 36,000 and 20,000 , respectively, whereas only one subunit with an apparent molecular weight of 50,000 dominates the $7 \mathrm{~S}$ vicilin oligomer. The primary translation product of legumin messenger RNA is a 60,000 molecular weight prolegumin containing the covalently linked $\alpha$-and $\beta$-subunits of legumin $(1,10,29)$. The same applies for soy bean glycinin (24). The globulins are synthesized in the mesophyll cells of the developing cotyledons $(14,19,28)$, and stored in protein bodies (31). Ultrastructural studies performed during the period of storage protein synthesis reveal a massive development of the rough endoplasmic reticulum $(5,11,22)$. Electrophoretic analysis of the polypeptides synthesized in vitro on free and initially membrane bound polysomes from developing Vicia faba and Phaseolus vulgaris cotyledons reveals that the globulin storage proteins are preferentially synthesized on the rough endoplasmic reticulum $(2,20,21,25,26,27)$. Likewise, it has been found that the storage proteins of the cereal endosperm - the prolamins - are synthesized on the endoplasmic reticulum $(4,17)$. The primary translation products are slightly larger than the mature prolamin polypeptides and processing of the precursor molecules to their final size takes place during their vectorial discharge into the lumen of the rough endoplasmic reticulum $(6,7,17)$. An analogous precursor molecule has been identified for pea vicilin (14).

In order to obtain more information on the storage protein synthesis and transport in the developing seeds of Vicia faba, we have isolated rough microsomes, initially membrane bound polysomes and polyadenylated mRNA from immature cotyledons. The isolated templates were translated in vitro and the synthesized polypeptides were subsequently isolated by immunoaffinity adsorption using antibodies raised against vicilin and legumin fractions and analyzed by SDS-polyacrylamide gel electrophoresis (PAGE).

\section{MATERIALS AND METHODS}

\subsection{Chemicals}

ATP (disodium salt), GTP (sodium salt), HEPES, creatinine phosphate (disodium salt), creatinine kinase (E.C. No. 2.7.3.2.), spermidine phosphate, $\alpha$-chymotrypsin, DTT and L-amino acids were purchased from Sigma Chemicals. ${ }^{35} \mathrm{~S}$-methionine (specific activity approx. 1200 $\mathrm{Ci} \cdot \mathrm{mmol}^{-1}$ ), ${ }^{3} \mathrm{H}$-leucine (specific activity approx. $130 \mathrm{Ci} \cdot \mathrm{mmol}^{-1}$, a rabbit reticulocyte system and ${ }^{14} \mathrm{C}$-methylated protein mixture $(5 \mathrm{mCi}$. $\mathrm{ml}^{-1}$ ) were obtained from Radiochemical Center, Amersham, U.K. ${ }^{14} \mathrm{C}$-protein hydrolysate $\left(1 \mathrm{mCi} \cdot \mathrm{ml}^{-1}\right)$ and ${ }^{14} \mathrm{C}$-aspartic acid $(0.54 \mathrm{mCi} /$ $2.5 \mathrm{ml}$ ) were purchased from UVVVR, Czechoslovakia. Protein A Sepharose 4 B, Poly (U) Sepharose 4 B and CNBr-activated Sepharose 4 $B$ were obtained from Pharmacia, Sweden.

HKM buffer A: 20 mM-HEPES, pH 7.6, 100 $\mathrm{mM}-\mathrm{K}$ acetate,

$50 \mathrm{~mm}-\mathrm{Mg}$ acetate, $0.2 \mathrm{M}$ sucrose and $2 \mathrm{mM}$-DTT

HKM buffer B: 20 mM-HEPES, pH 7.6, 100 $\mathrm{mM}-\mathrm{K}$ acetate, $5 \mathrm{~mm}-\mathrm{Mg}$ acetate and $2 \mathrm{~mm}$ DTT

Tris-buffer: $\quad 50 \mathrm{~mm}-\mathrm{Tris}-\mathrm{HCl}, \mathrm{pH} 7.7$, $0.15 \mathrm{M}-\mathrm{NaCl}$,

2\% Triton X-100, $10 \mathrm{mm-}$ methionine

\subsection{Plant material}

Vicia faba L. var. minor, cv. Fribo were grown under controlled environmental conditions in the phytotron at Gatersleben. Seed cotyledons were harvested at the stage of active storage globulin synthesis (32-36 days after flowering), immediately frozen in liquid nitrogen, and subsequently stored in polyethylene bags at $-70^{\circ} \mathrm{C}$ for up to 3 months. Barley spikes (Hordeum vulgare L.) cv. Bomi were harvested 20 days after fertilisation, frozen in liquid nitrogen, and stored at $-70^{\circ} \mathrm{C}$.

\subsection{Polysome isolation}

Membrane bound polysomes were detached from isolated rough microsomes with $1 \%$ Triton X-100 and isolated as described previously (4). 


\subsection{Preparation of rough and stripped microsomes}

Rough microsomes were isolated and stripped microsome membranes prepared with EDTA as described previously $(7,8)$.

\subsection{Preparation of polyadenylated mRNA}

Poly-A containing RNA was isolated from immature cotyledons by three times repeated affinity chromatography on poly-U Sepharose according to VASSART et al. (30) as described previously (26).

\subsection{Cell-free protein synthesis}

In vitro translation of membrane bound polysomes and rough microsomes was performed in the wheat germ system $(7,8)$. A commercial rabbit reticulocyte lysate derived system was used for the cell-free protein synthesis directed by mRNA $(2.3 \mu \mathrm{g}$ RNA/ $20 \mu \mathrm{l}$ assay).

\subsection{Immunoglobin (IgG) preparation}

The procedure for $\operatorname{IgG}$ preparation was essentially the same as described by $z$. NIEDEN et al. (23). Rabbits were immunized with purified preparations of vicilin and legumin (18). The IgG fraction was isolated by ammonium sulfate precipitation from pooled antisera with high titres followed by affinity chromatography on the appropriate antigen covalently linked to CNBr-activated Sepharose 4 B (Pharmacia, Sweden).

Pre-immune IgG for control reactions was prepared by affinity chromatography on goat anti-rabbit-IgG covalently linked to Sepharose.

\subsection{Immunoaffinity isolation of globulin polypeptides synthesized in vitro and in vivo}

Globulin polypeptides were isolated by a modified immunosorbent technique (15) using specific $\operatorname{lgG}$ against vicilin and legumin, and Protein A-Sepharose. Aliquots of cell-free translation assays representing about $1 \times 10^{6} \mathrm{cpm}$ were adjusted to equal concentrations of wheat germ extract. The samples were diluted with 50
mM-Tris $/ \mathrm{HCl}, \mathrm{pH} \mathrm{7.7,} \mathrm{containing} 2 \%$ Triton $\mathrm{X}-100,0.15 \mathrm{~m}-\mathrm{NaCl}$ and $10 \mathrm{~mm}-$ methionine to a final volume of $600 \mu \mathrm{l}$ and incubated for 1 hour at room temperature to dissolve the membranes. Undissolved materials were removed by centrifugation $(13,000 \mathrm{~g}, 10 \mathrm{~min})$ and supernatants were incubated for $30 \mathrm{~min}$ with pre-immune $\mathrm{IgG}$ followed by Protein A-Sepharose $(30 \mathrm{~min})$. Vicilin and legumin polypeptides were isolated from the same supernatant by sequential treatments with the appropriate IgG-preparations and Protein A-Sepharose for 1 hour each at room temperature. Bound proteins were released from the sorbent by elution under denaturing conditions.

Immunoprecipitation of in vivo labelled globulin polypeptides was performed using specific IgG ( 2 hours, room temperature) and an excess of goat anti-rabbit IgG (overnight, $4^{\circ} \mathrm{C}$ ).

\subsection{In vivo labelling of globulins}

Immature cotyledons from freshly harvested seeds at the stage of intensive storage globulin biosynthesis were incubated on Parafilm with 12 $\mu \mathrm{Ci} /$ cotyledon of a mixture $(3: \mathrm{I}, \mathrm{v} / \mathrm{v})$ of ${ }^{14} \mathrm{C}$ protein hydrolysate $\left(1 \mathrm{mCi} \cdot \mathrm{ml}^{-1}\right)$ and ${ }^{14} \mathrm{C}$ aspartic acid $(0.54 \mathrm{mCi} / 2.5 \mathrm{ml})$ for $20 \mathrm{~min}$ up to 1 hour at room temperature. Globulins were immunoprecipitated (see 2.8) from isolated microsome fractions after dissolution of the microsomal membranes with 0.1 M-phosphate buffer, $\mathrm{pH} 7.0,0.5 \mathrm{M}-\mathrm{NaCl}, 0.5 \% \mathrm{DOC}$ and $1 \%$ Triton X-100.

\subsection{SDS-PAGE and fluorography of in vitro synthesized polypeptides}

Electrophoresis was performed under denaturing conditions in $12.5 \%$ polyacrylamide gels according to LAEMMLI (16). The gels were prepared for fluorography by $20 \mathrm{~min}$ incubation in $1 \mathrm{M}$-sodium salicylate as described by CHAMBERLAIN (9) and exposed to RP Royal X-Omat film (Kodak) at $-70^{\circ} \mathrm{C}$ for $1-10$ days, and then developed. 


\section{RESULTS}

3.1. Isolation and characterization of membrane bound polysomes and rough microsomes

Fractionation of crude organelle preparations, i.e. $37,000 \times \mathrm{g}$ pellets on a discontinuous sucrose gradient resulted in three distinct bands at the interfaces of $0.2 \mathrm{M}-1.5 \mathrm{~m}$ (band I), $1.5 \mathrm{M}$ -1.75 (band II), and $1.75 \mathrm{M}-2.26 \mathrm{M}$ (band III)sucrose, respectively. The upper faint band (I) consisted mainly of small, possibly dictyosomederived vesicles and of small amounts of microsomes, whereas ribosome studded membrane vesicles were abundant in the fraction banding at the $1.5 \mathrm{~m}-1.75 \mathrm{~m}$ sucrose interface (band II). Rough membrane fractions obtained from band II by puncturing the centrifuge tube with a hypodermic needle exhibited a $\mathrm{A}_{260} / \mathrm{A}_{280}$ ratio of 1.23 , compared to a ratio of 1.8 obtained for purified polysomes.

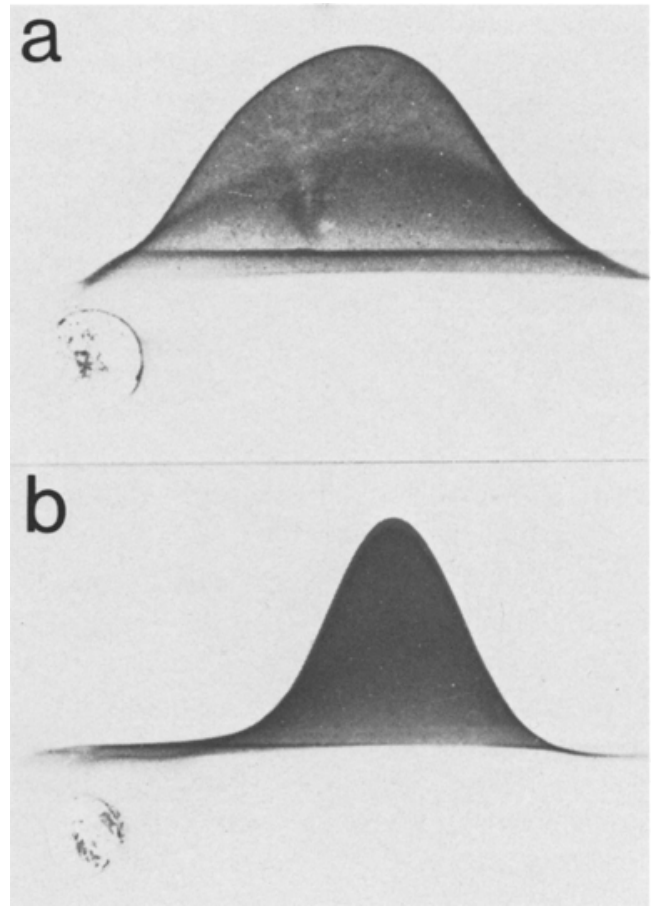

Figure 1. Crossed immunoelectrophoresis of crude globulin extracts with purified IgG preparations, directed against vicilin (a) and legumin (b). Single precipitation arcs are observed.

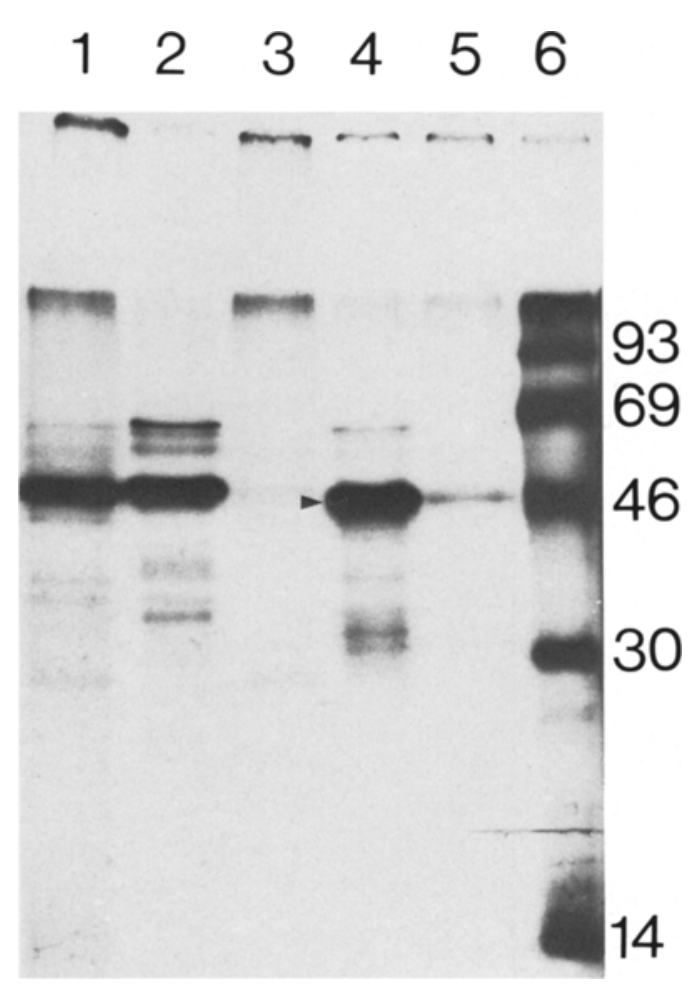

Figure 2. SDS-polyacrylamide gel electrophoresis of vicilin polypeptides synthesized in vitro using either 35S-methionine (tracks $1-3$ ) or $3 \mathrm{H}$-leucine as the protein label (tracks 4-5).

Cell free protein synthesis, isolation by immunoaffinity, SDS-polyacrylamide gel electrophoresis and fluorography were as described under Materials and Methods $(2.6,2.8,2.10)$. The templates were as follows: Initially membrane bound polysomes in tracks 1 and 4 , poly-A mRNA in track 2 and rough microsomes in tracks 3 and 5 . Arrows indicate the difference in apparent molecular weight between vicilin synthesized with $35 \mathrm{~S}$-methionine which labels only the $\mathrm{N}$-terminal of the precursor and vicilin synthesized with ${ }^{3} \mathrm{H}$-leucine which labels also in the non-precursor part of the molecule. Compare tracks 1 to 3 with 4 and 5 . Track 6 contains protein markers with molecular weights $\times 10^{-3}$ as indicated.

\subsection{Characterization of the anti-vicilin and anti-legumin preparations}

The immunoglobulin preparations were isolated by ammonium sulfate precipitation, followed by immunoaffinity chromatography (see Materials and Methods, 2.7). Their specificity was analyzed by crossed immunoelectrophoresis, 


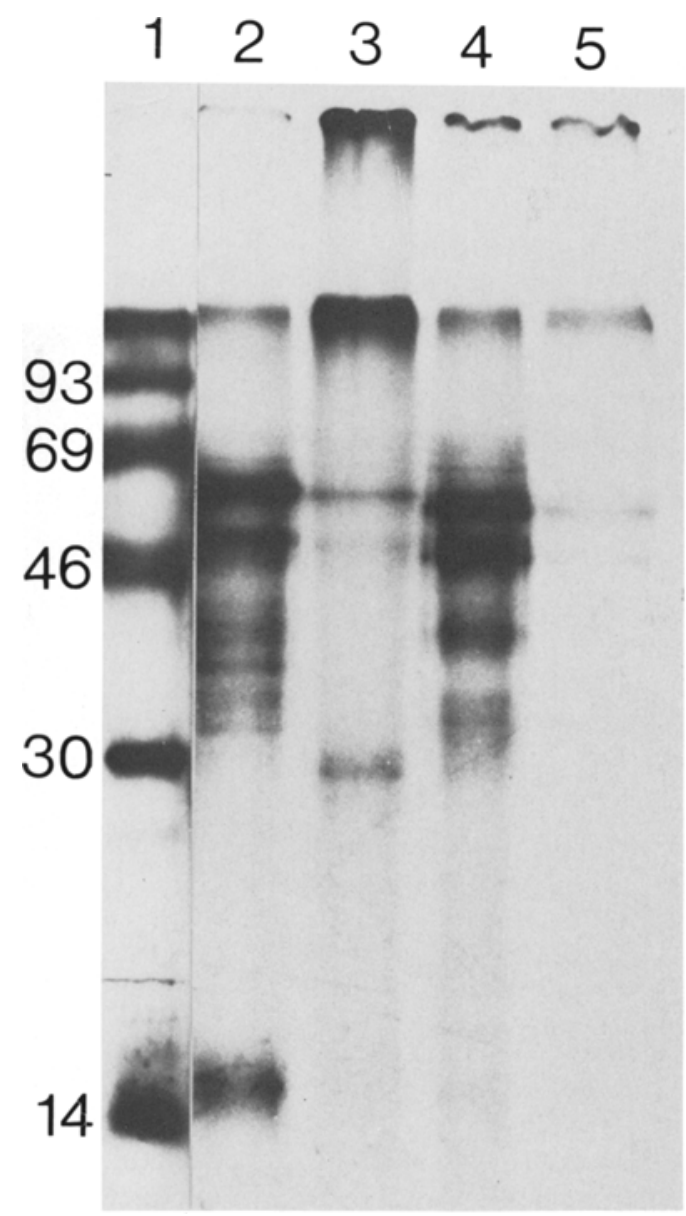

Figure 3. SDS-polyacrylamide gel electrophoresis of polypeptides synthesized in vitro using either 35Smethionine (tracks 2 and 3 ) or $3 \mathrm{H}$-leucine (tracks 4 and 5) as the protein label and isolated by antibodies raised against legumin.

The templates were as follows: Initially membrane bound polysomes in track 4 , poly-A mRNA in track 2 and rough microsomes in tracks 3 and 5 . Track 1 contains molecular weight markers with molecular weights $\times 10^{-3}$ as indicated. For further details see 2.6, 2.8 and 2.10 under Materials and Methods.

using crude globulin fractions in the first dimension. Single precipitation arcs were obtained for both vicilin and legumin antibodies (Figure 1).

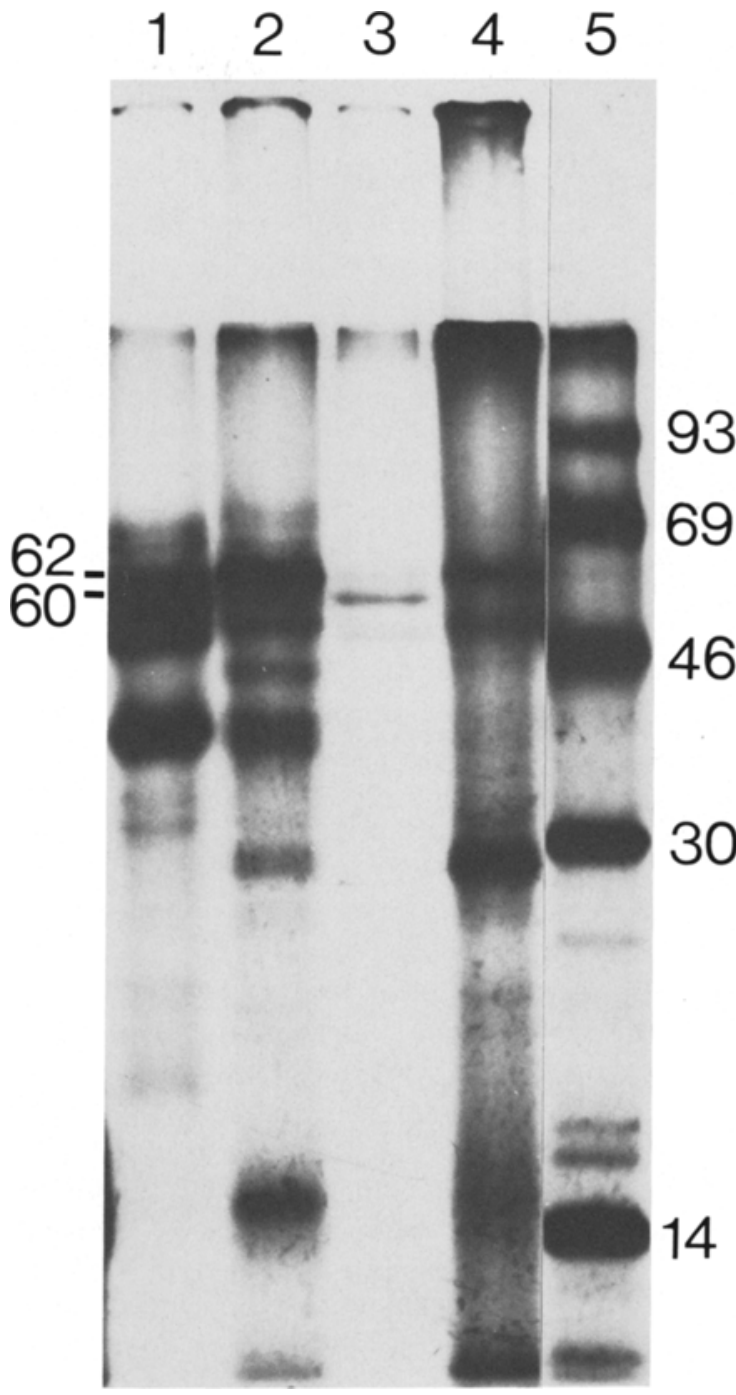

Figure 4. SDS-polyacrylamide gel electrophoresis of polypeptides synthesized in vitro using either ${ }^{3} \mathrm{H}$ leucine (tracks 1 and 3) or 35S-methionine (tracks 2 and 4) and isolated with antibodies raised against legumin.

The templates were as follows: Initially membrane bound polysomes (tracks 1 and 2) and microsomes (tracks 3 and 4). Track 5 contains molecular weight markers $\left(\times 10^{-3}\right)$.

\subsection{Cell-free protein synthesis}

A 20-33 fold stimulation over the wheat germ control was obtained with rough microsomes and detached polysomes as the templates. 
Polyadenylated mRNA stimulated the rabbit reticulocyte system approximately 25 fold.

\subsection{Translation products on initially membrane bound polysomes, microsomes and polyadenylated $\mathrm{mRNA}$}

Figures 2 and 3 depict the polypeptides synthesized by the three different templates. The two sets of polypeptides were isolated sequentially with antibodies raised against vicilin (Figure 2) and legumin (Figures 3 and 4) from the same reaction mixture. The specific polypeptide patterns obtained after SDS-polyacrylamide gel electrophoresis were independent of the order by which the immunoaffinity isolation was performed. Vicilin was synthesized in vitro on mRNA templates as one major polypeptide with an apparent molecular weight of 52,000 , and minor components with molecular weights around 60,000 to 70,000 and 30,000 (Figure 2, track 2). The 52,000 mol.wt. vicilin polypeptide was the predominant translation product also of initially membrane bound polysomes, when ${ }^{35} \mathrm{~S}$-methionine was the protein label (Figure 2, track 1). Only a very weak fluorographic image could be detected in the 52,000 mol.wt. region on the original fluorogram, when an attempt was made to label microsomal translation products with ${ }^{35} \mathrm{~S}$-methionine (Figure 2, track 3). Translation of microsomes with ${ }^{3} \mathrm{H}$-leucine as the label resulted, however, in a more prominent vicilin polypeptide with a molecular weight of 50,000 (Figure 2, track 5), which is identical to the molecular weight of the major translation product from initially membrane bound polysomes, employing ${ }^{3} \mathrm{H}$-leucine (Figure 2, track 4). Thus the major translation product labelled with radioactive leucine was always significantly smaller than that visualised with radioactive methionine. A similar relationship could be deduced for the $68,000 \mathrm{~mol}$.wt. translation product (Figure 2, track 2) and the 66,000 mol.wt. polysomal translation product (Figure 2, track 4).

The antibodies raised against a legumin fraction isolated from the translation products a number of polypeptides ranging from 62,000 to 15,000 in apparent molecular weight. The 62,000 mol.wt. polypeptide is considered to correspond to the 60,000 mol.wt. prolegumin identified by CROY et al. (10). Using ${ }^{35} \mathrm{~S}-$ methionine the mRNA product (Figure 3, track 2), the microsome product (Figure 3, track 3, Figure 4, track 4) and the polysome product (Figure 4, track 2) of this polypeptide have the same electrophoretic mobility (62,000 mol.wt.). Using ${ }^{3} \mathrm{H}$-leucine the polysome product (Figure 3, track 4, Figure 4, track 1) and the microsome product (Figure 3, track 5, Figure 4, track 3 ) of the largest polypeptide appear as a double band with molecular weights of 62,000 and 60,000 , the latter being more prominent than the former. The 60,000 mol.wt. band is also observed, when ${ }^{3} \mathrm{H}$-leucine is used for labelling the mRNA translation product.

The above described situation applies also to the prominent translation product pair with apparent molecular weights of 53,000 and 51,000 . The nature of the translation products with apparent molecular weights of 15,000 to 40,000 recognized by the antibody preparation remains for the time being unknown.

\subsection{In vivo biosynthesis of vicilin and legumin polypeptides}

Rough microsomes were isolated after in vivo labelling of immature cotyledons with a ${ }^{14} \mathrm{C}$ amino acid mixture in order to investigate the molecular composition of globulin polypeptides synthesized inside the cell. SDS-polyacrylamide gel electrophoresis and fluorography of antivicilin immunoprecipitated polypeptides extracted from microsome preparations (Figure 5, track 1) revealed that the cotyledons synthesized one major polypeptide with a molecular weight of approximately 50,000 corresponding to the major polypeptide translated in vitro (Figure 2). One additional polypeptide with a molecular weight of 57,000 was also immunoprecipitated. Whether this polypeptide corresponds to any of the in vitro translation products cannot be decided, as is the case with the lower molecular weight bands. The pattern of in vivo labelled polypeptides which could be isolated from microsomal preparations with antibodies raised against a legumin fraction is presented in Figure 5 , track 2 . Among them can be recognized the $\alpha$ and $\beta$-subunits consisting of several bands around a molecular weight of 36,000 and 22,000 , respectively. Two prominent bands with 


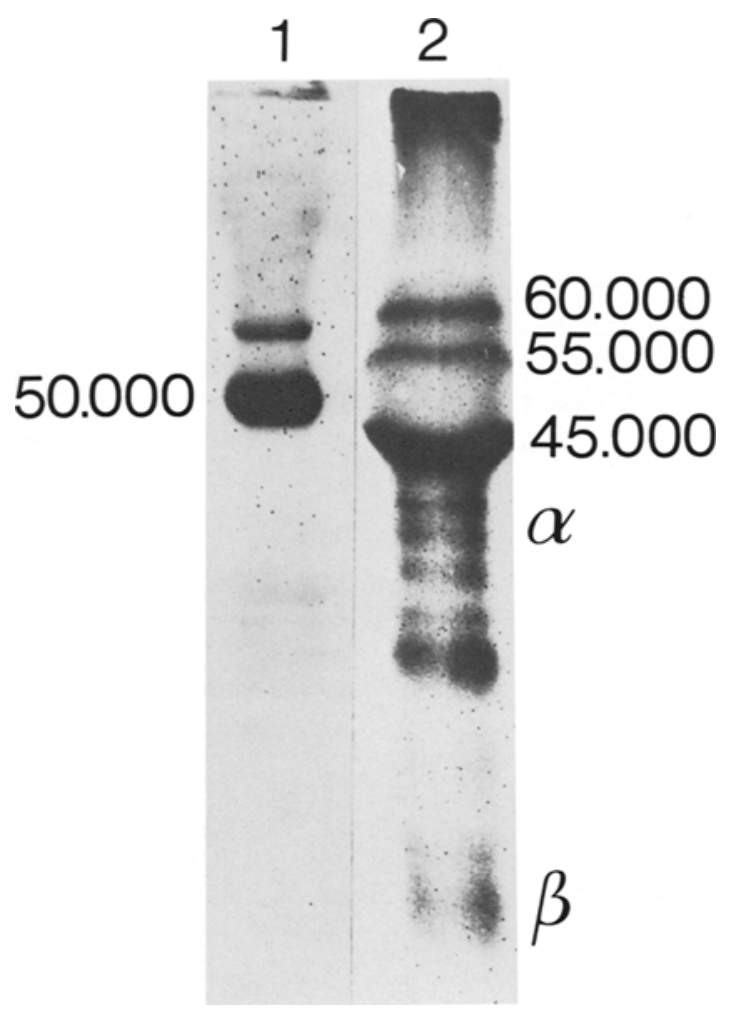

Figure 5. SDS-polyacrylamide gel electrophoresis of in vivo synthesized vicilin and legumin related polypeptides.

Immature cotyledons were incubated with $14 \mathrm{C}$ labelled amino acids. Vicilin and legumin polypeptides were immunoprecipitated from isolated detergent solubilized microsomes prior to electrophoresis (see Materials and Methods 2.8 and 2.9). Track 1 : unreduced vicilin, track 2: legumin reduced with $\beta$ mercaptoethanol prior to electrophoresis. The band with the highest molecular weight is considered to be the 60,000 mol.wt. legumin precursor identified by Croy et al. (10), $\alpha$ and $\beta$ mark the positions of the 36,000 and $20,000 \mathrm{~mol}$.wt. legumin subunits, respectively. Two additional reduced globulins with apparent molecular weights around 55,000 and 45,000 were isolated by the antibodies from the microsomal extracts. The distortion of the gel is due to the presence of high amounts of unlabelled reduced IgG.

approximate molecular weights of 60,000 and 55,000 are present and could correspond to the polypeptides of this size labelled in the in vitro translation experiments (Figures 3 and 4). An additional heavy band of unknown composition is present at the lower end of the bulge caused by the accumulation of reduced $\mathrm{IgG}$ chains.

\subsection{Transfer of in vitro synthesized globulin polypeptides into the lumen of the endoplasmic reticulum}

Initially membrane bound polysomes and microsomes, isolated from developing cotyledons of Vicia faba, were translated in vitro and posttranslationally treated with trypsin for 30 min at room temperature in the presence or absence of $1 \%$ Triton X-100 (Figure 6). The trypsin treatment resulted in a complete digestion of the polysomal products, whereas the vicilin polypeptides and the legumin related polypeptides synthesized on the microsomal membrane, were quite inaccessible to proteolytic attack (Figure 6, tracks 3 and 6). This protection was lost upon solubilisation of the endoplasmic reticulum membrane with detergent (Figure 6 , tracks 2 and 5).

\subsection{Reconstitution of functional hybrid rough microsomes from barley polyribosomes and stripped microsomes from Vicia faba cotyledons}

It has been shown earlier that the storage proteins of the barley endosperm - the hordeins - are vectorially discharged into the lumen of the endoplasmic reticulum $(7,8)$. Hordein polypeptides, synthesized in vitro on rough microsomes, are protected from chymotryptic digestion by the microsomal membrane (Figure 7, track 2). When initially membrane bound polysomes, isolated from barley endosperm were combined with stripped microsomes from Vicia faba cotyledons and used to program the protein synthesizing system based on wheat germ extract functional microsomes were formed, and a fraction of the synthesized hordein polypeptides were protected from proteolysis by the Vicia faba membranes (Figure 7, track 3), indicating interspecies reconstitution of functional rough microsomes. If the reconstituted microsomes were treated with Triton X-100 the synthesized polypeptides became accessible to chymotrypsin digestion. 


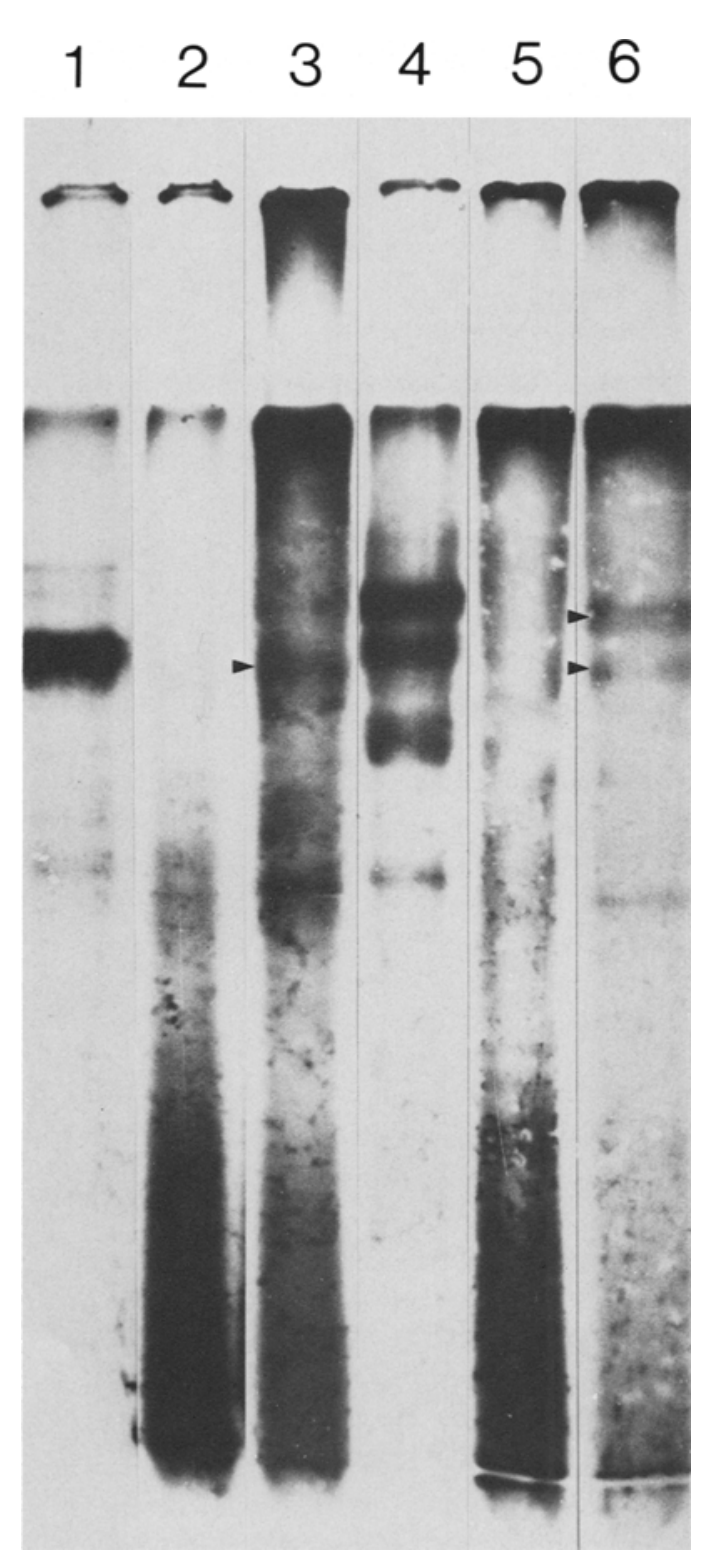

Figure 6. SDS-polyacrylamide gel electrophoresis of vicilin and legumin polypeptides synthesized in vitro with rough microsomes and polysomes as templates.

Cell-free protein synthesis was performed with rough microsomes and polysomes isolated from immature Vicia faba cotyledons. Vicilin and legumin polypeptides, remaining after $30 \mathrm{~min}$ trypsin treatment $\left(40 \mu \mathrm{g} \cdot \mathrm{ml}^{-1}\right.$ assay $)$ in the presence or absence of $1 \%$ Triton X-100 were immunoaffinity isolated after enzyme inactivation using an excess of trypsin inhibitor. Immunoaffinity isolation, electrophoresis and fluorography were performed as described under Materials and Methods $(2.8,2.10)$. The fluorogram shows translation products after the following treatments:

$\begin{array}{ccccc}\text { Track } & \text { Template } & \text { IgG } & \text { sin } & \text { X-100 } \\ 1 & \text { membrane bound } & & & \\ & \text { polysomes } & \text { anti vicilin } & - & - \\ 2 & \text { rough microsomes } & \text { anti vicilin } & + & + \\ 3 & \text { rough microsomes } & \text { anti vicilin } & + & - \\ 4 & \text { membrane bound } & & & \\ & \text { polysomes } & \text { anti legumin } & - & - \\ 5 & \text { rough microsomes } & \text { anti legumin } & + & + \\ 6 & \text { rough microsomes } & \text { anti legumin } & + & -\end{array}$

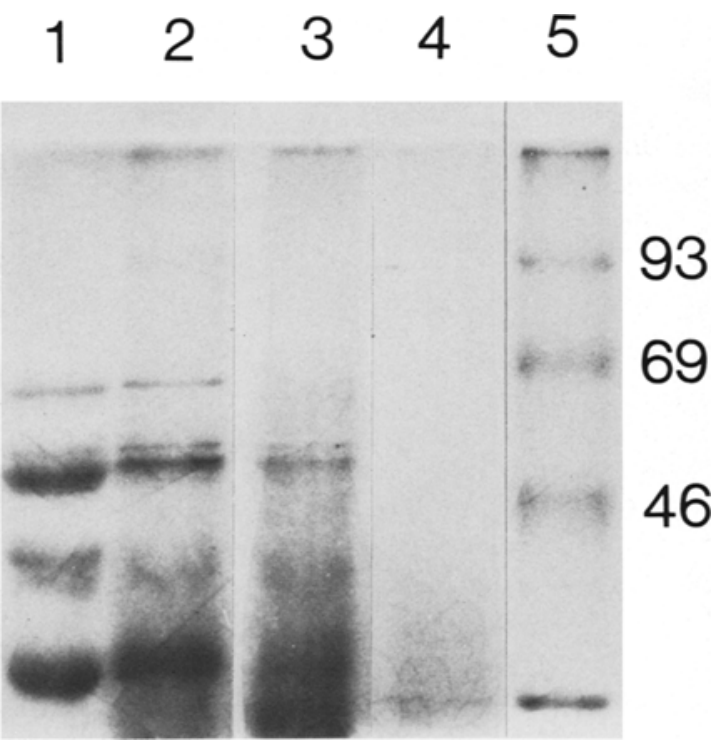

Figure 7. SDS-polyacrylamide gel electrophoresis of $55 \%$ isopropanol soluble in vitro translation products of rough microsomes reconstituted from Vicia faba stripped microsomes and barley membrane bound polysomes.

Cell free translation was also performed with rough microsomes and polysomes prepared from 20 day old Bomi barley endosperms. The $55 \%$ isopropanol soluble translation products remaining after 2 hours chymotrypsin treatment at $2^{\circ} \mathrm{C}$ were analyzed by electrophoresis and fluorography as described under Materials and Methods (2.10). The fluorogram shows translation products of barley rough microsomes (track 2), reconstituted rough hybrid microsomes (track 3) and barley polysomes (track 4), all posttranslationally treated with chymotrypsin. Track 1 contains in vivo labelled authentic hordein and track 5 molecular weight markers. 


\section{DISCUSSION}

\subsection{Cell free synthesis of Vicia faba vicilin}

PüCHEL et al. (26) translated free and initially membrane bound polysomes, isolated from developing cotyledons of Vicia faba in vitro and found that legumin and vicilin were preferentially synthesized on the membrane bound polysomes. Vicilin was also detected as a translation product in an in vitro system programmed by polyadenylated mRNA (1). This paper shows that vicilin is synthesized as a major precursor polypeptide of about 52,000 molecular weight. The vicilin precursor was labelled intensively with ${ }^{35} \mathrm{~S}$-methionine when membrane bound polysomes and mRNA were employed as the template (Figure 2, tracks 1 and 2), even though vicilin is known to be devoid of sulfur containing amino acids (3). If ${ }^{35} \mathrm{~S}$-methionine is only incorporated as the $\mathrm{N}$-terminal amino acid in the vicilin precursor, we would expect the polypeptide, which has been vectorially discharged into the lumen of the endoplasmic reticulum and there lost its $\mathrm{N}$-terminal signal peptide not to be labelled significantly. This is brought out by the deficiency in methionine labelling in the translation product of rough microsomes (Figure 2, track 3). On the other hand with ${ }^{3} \mathrm{H}$-leucine considerable label could be incorporated into the translation product of the rough microsomes (Figure 2, track 5). This product as well as the product of polysomes labelled with leucine (Figure 2, track 4) displayed a lower molecular weight of 50,000 corresponding thus in size to native vicilin. The position of the single methionine as the $\mathrm{N}$-terminal amino acid in the vicilin polypeptide obtained from mRNA could thus be exploited to establish the precursor product relationship between the primary translation product and the ${ }^{3} \mathrm{H}$-leucine labelled microsomal translation product. It was also established that the ${ }^{3} \mathrm{H}$-leucine labelled translation product of mRNA had the previcilin molecular weight of 52,000 . The fact that ${ }^{3} \mathrm{H}$-leucine labelled previcilin is not recognizable as translation product of polysomes (Figure 2, track 4), is most likely explained by a poor reinitiation in the wheat germ system.

\subsection{Cell free synthesis of Vicia faba legumin}

$\mathrm{Pea}$, and Vicia faba legumin is synthesized as a precursor polypeptide with an approximate molecular weight of $60,000(1,10,12)$. This precursor qualifies for the name prolegumin since it is subsequently cleaved proteolytically into separate $\alpha$ - and $\beta$-legumin subunits (10).

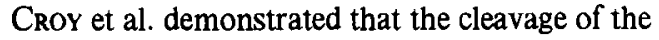
prolegumin is not a cotranslational event, since significant amounts of the precursor were present in extracts prepared from developing pea seeds. The antibody preparation used in this study reacted with in vitro translation products having an apparent molecular weight of 62,000 and 60,000 which can be considered as prolegumins. However, it was not possible to establish a precursor-product relationship between the 62,000 and $60,000 \mathrm{~mol}$.wt. polypeptides. The antibodies reacted also with several in vitro translation products of lower molecular weights. The analysis of in vivo synthesized polypeptides with the same antibody preparation identified newly synthesized $\alpha$ - and $\beta$-legumin subunits, the putative prolegumin of $60,000 \mathrm{~mol}$.wt. as well as several other polypeptides. While superficial relationships in size between these in vitro and in vivo synthesized polypeptides can be intimated, no decisive conclusions can be drawn.

\subsection{Reconstitution of functional hybrid microsomes from Vicia faba stripped microsomes and barley endosperm polysomes}

Higgins and SPENCER (14) showed that addition of dog or pea microsomal membranes during translation of pea polysomal RNA in vitro, resulted in processing of the vicilin precursor to authentic vicilin. We report here the reconstitution of functional rough microsomes from Vicia faba stripped microsomal membranes and initially membrane bound polysomes, isolated from barley endosperm. Figure 7 reveals that the reconstituted hybrid microsomes synthesize barley endosperm storage protein, and discharge it through the endoplasmic reticulum membrane obtained from Vicia faba seeds. Whether these results taken together with the data obtained by HigGins and SPENCER (14) signify an evolutionary conserved apparatus for the initial steps in the transport mechanism for plant storage proteins and animal secretory protein remains to be substantiated by further experiments. 


\section{ACKNOWLEDGEMENTS}

The authors wish to thank professor D. voN WETTSTEIN for critical reading of the manuscript and AnN-Sofi Steinholz and Helga Stoll for the photographic work. ERNST WeBER was recipient of a Danish State Scholarship 1981.

\section{REFERENCES}

1. BASSÜNER, R.: In vitro Translationsversuche zur Analyse der Biosynthese von Reserveproteinen in reifenden Samen der Ackerbohne (Vicia faba L.) Ph. D. Thesis, Akad. Wiss. DDR, Berlin (1981)

2. Bollini, R. \& M. J. Chrispeels: The rough endoplasmic reticulum is the site of reserveprotein synthesis in developing Phaseolus vulgaris cotyledons. Planta 146, 487-501 (1979)

3. Boulter, D. \& E. Derbyshire: Taxonomic aspects of the structure of legume proteins. In: Chemotaxonomy of the Leguminosae, J. B. Harborne, D. Boulter and B. L. Turner eds., London, New York pp. 285-308 (1971)

4. BRANDT, A. \& J. INGVERSEN: In vitro synthesis of barley endosperm proteins of wild type and mutant templates. Carlsberg Res. Commun. 41, 311-320 (1976)

5. Briarty, L. G., D. A. Coult \& D. Boulter: Protein bodies of developing seeds of Vicia faba L. J. Exp. Bot. 20, 358-372 (1969)

6. BURR, F. A. \& B. BURR: In vitro uptake and processing of prezein and other maize preproteins by maize membranes. J. Cell Biol. 90, 427434 (1981)

7. Cameron-Mills, V., J. Ingversen \& A. Brandt: Transfer of in vitro synthesized barley endosperm proteins into the lumen of the endoplasmic reticulum. Carlsberg Res. Commun. 43, 91102 (1978)

8. Cameron-Mills, V. \& J. Ingversen: In vitro synthesis and transport of barley endosperm proteins: Reconstitution of functional rough microsomes from polyribosomes and stripped microsomes. Carlsberg Res. Commun. 43, 471489 (1978)

9. Chamberlain, J.P.: Fluorographic detection of radioactivity in polyacrylamide gels with the water-soluble fluor, sodium salicylate. Anal. Biochem. 98, 132-135 (1979)

10. Croy, R. R. D., J. A. Gatehouse, M. I. Evans \& D. Boulter: Characterization of the storage protein subunits synthesized in vitro by polyribosomes and RNA from developing pea (Pisum sativum L.) I. Legumin. Planta 148, 49-56 (1980)
11. Dieckert, J. W. \& M. C. Dieckert: The chemistry and cell biology of the vacuolar proteins of seeds. J. Food Sci. 41, 475-482 (1976)

12. Evans, M. I., R. R. D. Croy, P. Hutchinson, D. Boulter, P. Payne \& M. E. Gordon: Cell-free synthesis of some storage protein subunits by polyribosomes and RNA isolated from developing seeds of pea (Pisum sativum L.) Planta 144 , 455-462 (1979)

13. Evans, M. I., R. R. D. Croy, P. Brown \& D. BoulTER: Synthesis of complementary DNA's to partially purified mRNAs coding for the storage proteins of Pisum sativum. Biochim. Biophys. Acta 610, 81-95 (1980)

14. Higgins, T. J. V. \& D. Spencer: Precursor forms of pea vicilin subunits. Modification by microsomal membranes during cell-free translation. Plant Physiol. 67, 205-211 (1981)

15. Jonassen, I., J. Ingversen \& A. Brandt: Synthesis of SP II albumin, $\beta$-amylase and chymotrypsin inhibitor $\mathrm{Cl}-1$ on polysomes from the endoplasmic reticulum of barley endosperm. Carlsberg Res. Commun. 46, 175-181 (1981)

16. LAEMmLI, U. K.: Cleavage of structural proteins during the assembly of the head of bacteriophage T4. Nature 227, 680-685 (1970)

17. Larkins, B. A. \& W. J. Hurkman: Synthesis and deposition of zein in protein bodies of maize endosperm. Plant Physiol. 62, 256-263 (1978)

18. Manteuffel, R. \& G. Scholz: Studies on seed globulins from legumes. V. Immunoelectrophoretic control of vicilin purification by gel filtration. Biochem. Physiol. Pflanzen 168, $277-$ 285 (1975)

19. Manteuffel, R., K. Müntz, M. Püchel \& G. Scholz: Phase-dependent changes of DNA, RNA and protein accumulation during the ontogenesis of broad bean seeds (Vicia faba L., var. minor). Biochem. Physiol. Pflanzen 169, 595-605 (1976)

20. Müntz, K., B. Parthier, O. Aurich, R. Bassüner, R. Manteuffel, M. Püchel, P. SchmidT \& G. Scholz: In vitro biosynthesis of vicilin and legumin subunits on membrane bound polysomes from developing cotyledons of Vicia faba L. In: Regulation of developmental processes in plants. Proc. Conf. Halle 1977, VEB Gustav Fischer Verlag, Jena p. 384 (1978)

21. Müntz, K., H. Bäumlein, R. Bassüner, R. Manteuffel, M. Püchel, P. Schmidt \& U. WoBus: The regulation of biosynthesis and accumulation of storage proteins during plant seed development. BPP-REVIEW. Biochem. Physiol. Pflanzen 176, 401-422 (1981) 
22. NeumanN, D. \& E. Weber: Formation of protein bodies in ripening seeds of Vicia faba $L$. Biochem. Physiol. Pflanzen 173, 167-180 (1978)

23. Nieden, U. z., R. Manteuffel, D. NeumanN \& E. Weger: Electron microscopic immunocytochemical localization of storage proteins in Vicia faba seeds. Eur. J. Cell Biol. in press

24. Nielsen, N. C., M. Moreirea, R. Straswick, M. A. Hermodson, N. Tumer \& V. M. Than: The structure of glycinin from soybeans. In: Proc. 2. Seed Protein Symp. Gatersleben 1980, Abhdig. Akad. Wiss. DDR, Abt. Math. Naturwiss. Tech., Akademie-Verlag Berlin pp. 73-94 (1981)

25. Payne, P. I. \& D. Boulter: Free and membrane bound ribosomes of the cotyledons of Vicia faba (L.). I. Seed development. Planta 84, 263-27I (1969)

26. Püchel, M., K. Müntz, B. Parthier, $O$. Aurich, R. Bassüner, R. Manteuffel \& $P$. Schmid: RNA metabolism and membranebound polysomes in relation to globulin biosynthesis in cotyledons of developing field beans (Vicia faba L.). Eur. J. Biochem. 96, 321-329 (1979)

27. Schmidt, P., R. Bassüner, R. Manteuffel, M.
Püchel \& H. W. JANK: Polysomes and poly(A)containing RNA of membrane-bound polysomes from developing broad bean seeds (Vicia faba $\mathrm{L}$. var. minor). In: Proc. 2. Seed Protein Symp. Gatersleben 1980, Abhdlg. Akad. Wiss. DDR, Abt. Math. Naturwiss. Techn, Akademie-Verlag Berlin pp. 229-230 (1981)

28. Sмiтн, D. L.: Nucleic acids, protein, and starch synthesis in developing cotyledons of Pisum arvense L. Ann. Bot. 37, 795-804 (1973)

29. Spencer, D., T. J. V. Higgins, S. C. Button \& R. DAveY: Pulse-labeling studies on protein synthesis in developing pea seeds and evidence of a precursor form of legumin small subunit. Plant Physiol. 66, 510-515 (1980)

30. Vassart, G., H. Brocas, P. Nokin \& J. E. DuMONT: Translation in Xenopus oocytes of thyroglobulin mRNA isolated by poly(U)-sepharose affinity chromatography. Biochim. Biophys. Acta 324, 575-580 (1973)

31. Weber, E., D. Neumann \& R. Manteuffel: Storage protein accumulation and formation of protein bodies in Vicia faba seeds. In: Proc. 2. Seed Protein Symp. Gatersleben 1980, Abhdlg. Akad. Wiss. DDR, Abt. Math. Naturwiss. Techn., Akademie-Verlag Berlin pp. 103-119 (1981) 